\title{
Review
}

\section{Genetic Heterogeneity of Alzheimer's Disease: Embracing Research Partnerships}

\author{
Benedetta Nacmias $^{\mathrm{a}, *}$, Silvia Bagnoli ${ }^{\mathrm{a}}$, Irene Piaceri ${ }^{\mathrm{a}}$ and Sandro Sorbi ${ }^{\mathrm{a}, \mathrm{b}}$ \\ ${ }^{a}$ Department of Neuroscience, Psychology, Drug Research and Child Health, University of Florence, Florence, \\ Italy \\ ${ }^{\mathrm{b}}$ IRCCS Don Gnocchi, Florence, Italy
}

Accepted 19 August 2017

\begin{abstract}
Studies on the genetics of Alzheimer's disease (AD) have revealed the complexity and heterogeneity of the disease. All our studies have supported this evidence and contribute to the current understanding of the genetic architecture of AD. This report reviews the success of our investigations, focusing on the implications and importance of the genetics of AD, and demonstrates the relevance of research strategies embracing partnerships.
\end{abstract}

Keywords: Alzheimer 's disease, autosomal dominant, genetic mutation, genetic risk factor

\section{FAMILIAL ALZHEIMER'S DISEASE: THE BEGINNING}

The qualitative and quantitative aspects of the genetic population of Italy have provided evidence that the country is a genetically heterogeneous nation. According to recent studies [1,2], there are several genetic groups in different areas of Italy, thus allowing us to study large families, affected by $\mathrm{AD}$, living in the north, central, and south of Italy with different genetic traits. Our group started collaborating with other centers in Italy in 1980 in order to create a DNA bio-bank collecting samples, not only of patients belonging to familial forms of Alzheimer's disease (FAD), but also from non-affected members of the same families. Genetic studies on FAD have provided evidence that $\mathrm{AD}$ is a genetically heterogeneous disorder and, over the last 30 years, several families have

\footnotetext{
${ }^{*}$ Correspondence to: Benedetta Nacmias, Department of Neuroscience, Psychology, Drug Research and Child Health, University of Florence, Viale Pieraccini 6, 50139, Florence, Italy. Tel.: +39 0557948910 / 0557948912; Fax: +39 0552758265; E-mail: nacmias@unifi.it.
}

been described in which AD is caused by an autosomal dominant gene defect. The genetic history of AD started in 1987 when, in collaboration with Peter St. George-Hyslop, a linkage analyses discovered the first chromosomal location of a defective gene on chromosome 21, thus providing new insights into the nature of FAD [3-7]. In the early 1990s, we studied Italian FAD families through extensive clinical investigations of patients, interviews with relatives, studies of medical records, pedigree analysis, and molecular genetic studies of family members, thereby contributing to the discovery of the pathogenic variations in all three AD candidate genes: Presenilin1 (PSEN1), Presenilin 2 (PSEN2), and Amyloid precursor protein (APP) [5-7].

In 1993, we found the APPVal717Ile mutation segregating with the disease in the first Italian families (FLO12 and FLO13) from central Italy [5]. The mutation was found in all those affected as well as in members below the age of onset of the disease, thus allowing a preclinical diagnosis. Since 1991 [4], 51 different pathogenetic mutations have been described in this gene in 121 families worldwide [8]; to date, 
38/51 families have been described as carrying the APPVal717Ile mutation.

Thanks to collaboration with Amalia Bruni in Lamezia Terme, in southern Italy, we have collected samples from the large Calabrian family, FAD4, which has been described in numerous generations since the 1700s and led to the discovery in 1995 [6] of PSEN1, the most important gene responsible for FAD. To date, 215 pathogenic mutations have been described in PSEN1 [8].

A collaborative effort in 2000 led to the identification of Nicastrin protein [9] as modulator of the presenilin-mediated notch/glp-1 signal transduction and $\mathrm{A} \beta \mathrm{PP}$ processing.

Moreover, thanks to collaboration with Gabriella Marcon in Udine, in northern Italy, we started collecting samples from several members of a large Italian $\mathrm{AD}$ family living in Udine (FLO10) described over several generations, associated with methionine to valine substitution at residue 239 of PSEN2 [7]. The FLO10 family is characterized by some peculiarities regarding clinical and neuropathologic phenotype compared to sporadic AD [10].

PSEN2 mutations are rare and mutated patients showed a remarkable variability in age of onset of symptoms, disease duration, and clinical presentation. Today the diagnostic and predictive genetic screening for causal mutations in APP, PSEN1, and PSEN2 is already available for patients and their relatives. In any case, causative mutations are only responsible for a small portion of autosomal dominant FAD patients. There are still other genetic factors to discover as most of the families are negative, thus an important proportion of genetic variants in $\mathrm{AD}$ pathology are yet to be identified. However, it should be considered that penetrance and gene expression can influence the effect of a mutation.

In our neurogenetics laboratory, we have identified pathogenetic mutations in 5\% (5/98), 13\% (13/98), and $3 \%(3 / 98)$ of the collected families referred for diagnostic screening for APP, PSEN1, and PSEN2, respectively. Only after 25 years of the description of the first pathogenetic mutation in the APP gene [4] has an Italian consensus protocol for Genetic Counseling and Testing for Alzheimer's disease and Frontotemporal Lobar Degeneration been reached [11]. The protocol has been developed in the context of the Italian Dominantly Inherited Alzheimer's and Frontotemporal Network (IT-DIAfN) project, a national network of centers of excellence with expertise in managing patients with familial $\mathrm{AD}$ and frontotemporal dementia (FTD) [12] facilitating research and clinical trials.

It is widely held that genetic counseling should be provided by a multidisciplinary team including a geneticist, a neurologist/geriatrician, and a psychologist/psychiatrist according to the following schedule: 1) initial consultation with tailored information on the genetics of the dementias; 2) clinical, psychological, and cognitive assessment; if deemed appropriate, 3 ) genetic testing following a structured decision tree for gene mutation search; 4) genetic testing result disclosure; 5) psychological support follow-up. This genetic counseling protocol provides Italian centers with a line of shared practice for dealing with the requests for genetic testing for familial $\mathrm{AD}$ and FTD from patients and at-risk relatives, who may also be eligible participants for novel prevention clinical trials [11].

In recent years, new biomarkers, such as amyloid$\beta$ (A $\beta$ ) accumulation in cerebrospinal fluid (CSF) and positron emission tomography (PET) imaging, have been included in $\mathrm{AD}$ diagnostic criteria [13] in addition to genetic mutations. Their use in clinical practice allows discrimination between healthy control subjects and AD but also could help to detect preclinical and prodromal AD [14-16]. The combination of neuroimaging, biomarkers, and genetic tests helps, in most cases, to clinically diagnose accurately.

However, we have recently described a case of dementia clinically compatible with the FTD spectrum in an APP Ala713Thr-mutation carrier in which both $\left[{ }^{18} \mathrm{~F}\right]$ Florbetapir PET uptake and $A \beta_{1-42} \mathrm{CSF}$ levels were normal [17]; thus the genetic diagnosis was in contrast with the lack of evidence of $A \beta$ pathology assessed by both CSF analysis and amyloid imaging. Even genetic analysis can sometimes help or complicate the diagnosis. Moreover, mutations in genes related to other types of dementia, such as FTD, can be detected in patients with AD phenotype [18-23].

For example, the mutation p.R406W in Microtubule associated protein Tau (MAPT), a known causal gene for FTD, has been repeatedly reported in pedigrees with a clinical presentation of $\mathrm{AD}$ [21]. Mutations in two other FTD genes, Progranulin $(G R N)$ and Chromosome 9 open reading frame 72 (C9orf72), have also been described in clinical $\mathrm{AD}$ cohorts $[22,23]$. It may be important to include screening of these genes in the genetic diagnostic work-up, because APP, PSEN1, and PSEN2 account only for a small proportion of autosomal dominant $\mathrm{AD}$. 


\section{GENETIC RISK FACTORS: A CONTINUOUS DISCOVERY}

Linkage studies on familial cases have revealed the genetic bases associated with the disease; however, they were not sufficient to explain late onset-sporadic forms (LOAD). LOAD is complex and genetically heterogeneous; genes and environmental risk factors contribute together to the onset and progression of the disease.

Technological advances in high-throughput genotyping and sequencing allow testing of several thousands of samples (and patients and controls) that can be used for genome-wide association studies (GWAS). GWAS in fact report genetic variants and loci that are enriched in populations with a disease trait compared with unaffected individuals.

The most important results have been possible thanks to collaborative strategies which have created genetic consortia such as Alzheimer's Disease Genetics Consortium (ADGC), Genetic and Environmental Risk in Alzheimer's disease (GERAD), European Alzheimer's Disease Initiative (EADI), Cohorts for Heart and Aging in Genomic Epidemiology (CHARGE), Genetic and Environmental Risk for Alzheimer's Disease (GERAD)/ Defining Genetic, Polygenic and Environmental Risk for Alzheimer's Disease (PERADES) Consortium, the Alzheimer's Disease Genetic Consortium (ADGC), the Cohorts for Heart and Aging Research in Genomic Epidemiology (CHARGE), and the European Alzheimer's disease Initiative (EADI). In 2013, the International Genomics of Alzheimer's Project (IGAP) was launched with all the consortia joined together.

GWAS and IGAP have significantly advanced knowledge regarding the genetic heterogeneity of $\mathrm{AD}$ by identifying 30 additional genetic risk loci [24]. Several GWAS were performed [25-29] and later combined in a meta-analysis [30, 31] to report new AD susceptibility loci in European populations. A GWAS in African Americans identified variants in Apolipoprotein E (APOE) and ATP-binding cassette transporter (ABCA7) as genome-wide significant [32]. A GWAS in Asian populations identified AD-associated genomewide significant variants in or near $A P O E$ and SORL1 [33].

Thanks to collaboration strategies, we have contributed to identifying new genetic variants [25, $29,31]$ implicated in AD. To date, there are 30 genes associated with $\mathrm{AD}$ (27 loci associated with $\mathrm{AD}$, mostly through GWAS) distributed on 14 chromosomes [24] confirming the genetic heterogeneity of the disease. Moreover, the GWA approach to the genetics of $\mathrm{AD}$ has made it possible to discover the implication of four biological pathways (immune response, endocytosis, cholesterol transport, and proteasome-ubiquitin activity) in the pathogenesis of the disease and as prime targets for AD therapeutic interventions.

The first and most important genetic risk factor was identified in the 1990s when a particular APOE genotype was associated to LOAD as it is involved in the A $\beta$ pathway [34]. In 1994, we analyzed the APOE gene polymorphism in a sample of Italian AD patients, confirming a significant association between epsilon 4 allele and AD $[35,36]$. Since then, the role of APOE has been confirmed by hundreds of papers, thus for 17 years the APOE gene on chromosome $19 \mathrm{q} 13.2$ was the only genetic risk factor for AD. Moreover in 2011 a shift of category of the APOE gene from 'risk factor' to 'major gene' was proposed, with semi-dominant inheritance [37] increasing the risk according to age in a collaborative study on 7,351 cases and 10,132 controls with Caucasian ancestry. Since the beginning of this century, several genetic variants in different genes have been analyzed. Following the increasing evidence that suggests a role for nerve growth factor (NGFB), brain-derived neurotrophic factor $(B D N F)$, nerve growth factor receptor $(N G F R)$, and neurotrophic tyrosine kinase receptors 1 and 2 (NTRK1 and NTRK2) in the GRBassociated binding protein $2(G A B 2)$ genes in $\mathrm{AD}$, we analyzed single nucleotide polymorphisms (SNPs) within these genes in a population of Italian $\mathrm{AD}$ patients and healthy controls. Our results suggested that genetic variants of the neurotrophic system and $G A B 2$ genes might confer susceptibility to AD [38, 39].

Neurotrophins are a family of proteins that are essential for the development, differentiation, and survival of neurons [40]. Polymorphisms in genes of the neurotrophin system may determine an increased risk for developing AD.

GRB-associated binding protein 2 (GAB2, 11q14.1) has been proposed as a candidate gene, but with contrasting results. GAB2 is a scaffolding protein [41], possibly affecting tau, amyloid, and other AD-related pathological mechanisms.

Moreover, we also analyzed the genotype and allele distributions of the Pro86Leu polymorphism of the Calcium homeostasis modulator 1 
(CALHM1) gene, rs5984894, in the protocadherin $11 \mathrm{X}$-linked $(P C D H 11 X)$ gene and PICALM (phosphatidylinositol-binding clathrin assembly protein) in Italian AD patients [42-44]. Our results did not confirm an association between the CALHM1 variation, the $P C D H 11 X$ or PICALM and AD, thus suggesting a genetic heterogeneity among the various populations. Furthermore, we have provided evidence of the importance of epistatic effect and epigenetics $[45,46]$ in the expression of genes involved in the disease.

In 1995, we studied the relationship between ApoE genotype and the clinical expression of the disease in $A P P$ mutated families and found that ApoE genotype influences the age at onset of the disease, providing evidence of epistatic effect [45]. In 2015, for the first time, we studied, how epigenetic changes (DNA methylation) in peripheral blood of $\mathrm{AD}$ patients can influence disease expression [46]. In fact, the several genetic factors (mutations and risk factors) already described cannot fully explain the onset and progression of $\mathrm{AD}$, especially for the sporadic form of the disease [24]. The scientific community considers the complex combination of genetic and environmental factors the major modifier for risk of the disease [47]. Epigenetic modifications of the DNA may occur during development or later during adult life and it is one of the ways through which environmental factors interact with genetic ones [48]. Up to now, DNA methylation changes have been investigated in brain tissues in all genes associated with familial AD cases (APP, PSEN1, PSEN2, and MAPT), but the results are contradictory. In 1990, the first studies dealing with DNA methylation levels in the brain of patients with AD reported no significant difference between brain DNA of AD patients compared with healthy subjects $[49,50]$. It is essential to take into account that the results are conflicting due to the different brain regions and the multiple cell types analyzed, indeed DNA methylation is a dynamic process that can produce tissue-specific changes [51] and differences are observed across different regions within the brain [52]. Our study on lymphocytes found a strong hypomethylation status $(<20 \%$ methylation) in the three gene promoters (APP, PSEN1, PSEN2) in Italian $\mathrm{AD}$ patients with respect to healthy control subjects, with statistically significant differences. Although our study analyzed lymphocytes, which are not representative of the methylation levels in the brain, this can complete the picture of the role of epigenetic mechanisms and their relation to the disease.

\section{CELLULAR AND ANIMAL MODELS TO STUDY AD: NEW STRATEGIES}

The study of large AD-affected families carrying genetic mutations in the three major causative genes allowed discovery of the main biochemical pathways involved in the disease. In fact, fibroblasts that express a genetic defect can be obtained with a simple skin biopsy from a mutated subject in order to study the primary pathophysiological mechanisms by which the disease develops.

Today, it is well known that oxidative stress and reduced antioxidant defenses are early events in the pathogenesis of $\mathrm{AD}$. By analyzing peripheral cells carrying APP and PSEN1 gene mutations, it has been possible to show altered levels of oxidative markers supporting the hypothesis that oxidative damage to lipid, protein, and DNA is an important early event in $\mathrm{AD}$ pathogenesis [53].

In one collaborative study, we demonstrated that in APP-mutated fibroblasts oligomeric structures of $A \beta_{1-40}$ and $A \beta_{1-42}$ accumulate quicker near the plasma membrane, and are internalized faster and mostly in APPV717I fibroblasts than in agematched healthy fibroblasts. This mechanism leads to an increase in the production of reactive oxygen species and subsequently to membrane-oxidative injury with a significant impairment of cellular antioxidant capacity [54].

The role of the cellular membrane in destabilization and permeabilization is one of the crucial steps to understanding amyloid cytotoxicity, which leads to early alterations in intracellular redox status and ion homeostasis that potentially culminate in cell death Recent data on primary fibroblasts from familial AD patients bearing APPVal717Ile, PS-1Leu392Val, or PS-1Met146Leu gene mutations suggest a protective role for raft cholesterol against amyloid toxicity in $\mathrm{AD}$ [55].

Moreover, induced pluripotent stem cells derived from skin fibroblasts from subjects carrying pathogenetic mutations may be a useful resource for in vitro modeling of familial AD [56], allowing the study of new therapeutic strategies against the disease [57].

The triple transgenic mice model ( $3 \times \mathrm{Tg}$ ), known to develop three key characteristics of AD dysfunction (memory impairment, amyloid plaques, and neurofibrillary tangles), has recently provided new insight. In this model, the power of dietary polyphenols against neurodegeneration has been studied by investigating the effects of oleuropein aglycone (OLE), the main phenol in extra virgin olive oil 
(EVOO). OLE administration ameliorates memory dysfunction and promotes the proliferation of newborn cells in the subgranular zone of the dentate gyrus of the hippocampus [58]. Recent findings support a beneficial effect of EVOO consumption on all major features of the $\mathrm{AD}$ phenotype (behavioral deficits, synaptic pathology, $A \beta$, and tau neuropathology) and demonstrate that autophagy activation is the mechanism underlying these biological actions. Thus, consumption of EVOO, a major component of the Mediterranean diet, has been associated with reduced incidence of AD [59].

In 2016, the AIRAlzh (Associazione Italiana Ricerca Alzheimer) Network was launched in Italy to create an Italian network of young researchers studying $\mathrm{AD}$ and other dementias [60]. The main goal of the network is to encourage collaboration between national dementia research centers of excellence to realize projects, proposed by young researchers, focused on the identification of potentially modifiable risk factors and mechanisms of $\mathrm{AD}$ and other dementias. Scientific projects are based on these specific fields: Biology (in vitro studies including genetics, biomarkers, and pathological mechanisms); Clinical studies (involving human subjects such as pilot studies of pharmacological treatments, neuropsychology, imaging, and epidemiology); and Biotechnology (application of advanced and emerging technologies for the diagnosis and monitoring of dementias). The network encourages synergies and cooperation between young researchers with different research profiles to stimulate a concrete impact on the diagnosis and prevention of $\mathrm{AD}$ and other dementias.

In conclusion, network strategies in the field of AD research have provided evidence of the complexity and heterogeneity of the disease and contributed to the understanding of the current genetic architecture of AD. Moreover, genetic studies have allowed the application of new methodologies based on the use of cell and animal models of AD in order to study new therapeutic approaches against the disease.

\section{DISCLOSURE STATEMENT}

Authors' disclosures available online (http://j-alz. com/manuscript-disclosures/17-0570r1).

\section{REFERENCES}

[1] Hay M. Genetic History of the Italians. Available from: https://www.academia.edu/6013628/
[2] di Luigi L, Sforza C, Menozzi P, Piazza A (2000) Storia e geografia dei geni umani, 2nd ed. Adelphi (collana Gli Adelphi), EAN 9788845915888.

[3] St George-Hyslop PH, Tanzi RE, Polinsky RJ, Haines JL, Nee L, Watkins PC, MyersRH, Feldman RG, Pollen D, Drachman D, Growdon J, Bruni A, Foncin JF, Salmon D, Frommelt P, Amaducci L, Sorbi S, Piacentini S, Stewart GD, Hobbs WJ, Conneally PM, Gusella JF (1987) The genetic defect causing familial Alzheimer's disease maps on chromosome 21. Science 235, 885-890.

[4] Goate A, Chartier-Harlin MC, Mullan M, Brown J, Crawford F, Fidani L, Giuffra L, Haynes A, Irving N, James L, Mant R, Newton P, Rooke K, Roques P, Talbot C, PericakVance M, Roses A, Williamson R, Rossor M, Owen M, Hardy J (1991) Segregation of a missense mutation in the amyloid precursor protein gene with familial Alzheimer's disease. Nature 349, 704-706.

[5] Sorbi S, Nacmias B, Forleo P, Piacentini S, Amaducci L, Provinciali L (1993) APP717 and Alzheimer's disease in Italy. Nat Genet 4, 10.

[6] Rogaev EI, Sherrington R, Rogaeva EA, Levesque G, Ikeda M, Liang Y, Chi H, Lin C, Holman K, Tsuda T, Mar L, Sorbi S, Nacmias B, Piacentini S, Amaducci L, Chumakov I, Cohen D, Lannfelt L, Fraser PE, Rommens JM, St GeorgeHyslop PH (1995) Familial Alzheimer's disease in kindreds with missense mutations in a gene on chromosome 1 related to the Alzheimer's disease type 3 gene. Nature 376, 775-778.

[7] Sherrington R, Froelich S, Sorbi S, Campion D, Chi H, Rogaeva EA, Levesque G, Rogaev EI, Lin C, Liang Y, Ikeda M, Mar L, Brice A, Agid Y, Percy ME, Clerget-Darpoux F, Piacentini S, Marcon G, Nacmias B, Amaducci L, Frebourg T, Lannfelt L, Rommens JM, St George-Hyslop PH (1996) Alzheimer's disease associated with mutations in presenilin 2 is rare and variably penetrant. Hum Mol Genet 5, 985-988.

[8] Alzheimer Disease. \& Frontotemporal Dementia Mutation Database. http://www.molgen.ua.ac.be/ADMutations/

[9] Yu G, Nishimura M, Arawaka S, Levitan D, Zhang L, Tandon A, Song YQ, Rogaeva E, Chen F, Kawarai T, Supala A, Levesque L, Yu H, Yang DS, Holmes E, Milman P, Liang Y, Zhang DM, Xu DH, Sato C, Rogaev E, Smith M, Janus C, Zhang Y, Aebersold R, Farrer LS, Sorbi S, Bruni A, Fraser P, St George-Hyslop P (2000) Nicastrin modulates presenilin-mediated notch/glp-1 signal transduction and betaAPP processing. Nature 407, 48-54.

[10] Marcon G, Giaccone G, Cupidi C, Balestrieri M, Beltrami CA, Finato N, BergonziP, Sorbi S, Bugiani O, Tagliavini F (2004) Neuropathological and clinical phenotype of an Italian Alzheimer family with M239V mutation of presenilin 2 gene. J Neuropathol Exp Neurol 63, 199-209.

[11] Bocchetta M, Mega A, Bernardi L, Di Maria E, Benussi L, Binetti G, Borroni B, Colao R, Di Fede G, Fostinelli S, Galimberti D, Gennarelli M, Ghidoni R, Piaceri I, Pievani M, Porteri C, Redaelli V, Rossi G, Suardi S, Babiloni C, Scarpini E, Tagliavini F, Padovani A, Nacmias B, Sorbi S, Frisoni GB, Bruni AC, SINdem Collaborators (2016) Genetic counseling and testing for Alzheimer's disease and frontotemporal lobar degeneration: An Italian consensus protocol. J Alzheimers Dis 51, 277-291.

[12] Moulder KL, Snider BJ, Mills SL, Buckles VD, Santacruz AM, Bateman RJ, Morris JC (2013) Dominantly Inherited Alzheimer Network: Facilitating research and clinical trials. Alzheimers Res Ther 5, 48.

[13] McKhann GM, Knopman DS, Chertkow H, Hyman BT, Jack CR Jr, Kawas CH, Klunk WE, Koroshetz WJ, Manly JJ, Mayeux R, Mohs RC, Morris JC, Rossor MN, 
Scheltens P, Carrillo MC, Thies B, Weintraub S, Phelps CH (2011) The diagnosis of dementia due to Alzheimer's disease: Recommendations from the National Institute on Aging-Alzheimer's Association workgroups on diagnostic guidelines for Alzheimer's disease. Alzheimers Dement 7, 263-269.

[14] Mormino EC, Betensky RA, Hedden T, Schultz AP, Amariglio RE, Rentz DM, Johnson KA, Sperling RA (2014) Synergistic effect of $\beta$-amyloid and neurodegeneration on cognitive decline in clinically normal individuals. JAMA Neurol 71, 1379-1385.

[15] Sperling R, Mormino E, Johnson K (2014) The evolution of preclinical Alzheimer's disease: Implications for prevention trials. Neuron 84, 608-622.

[16] Sun Y, Yang FC, Lin CP, Han Y (2015) Biochemical and neuroimaging studies in subjective cognitive decline: Progress and perspectives. CNS Neurosci Ther 21, 768-775.

[17] Lombardi G, Berti V, Tedde A, Bagnoli S, Piaceri I, Polito C, Lucidi G, Ferrari C, Ginestroni A, Moretti M, Pupi A, Nacmias B, Sorbi S (2017) Low florbetapir PET uptake and normal A $31-42$ cerebrospinal fluid in an APP Ala713Thr mutation carrier. J Alzheimers Dis 57, 697-703.

[18] Redaelli V, Rossi G, Maderna E, Kovacs GG, Piccoli E, Caroppo P, Cacciatore F, Spinello S, Grisoli M, Sozzi G, Salmaggi A, Tagliavini F, Giaccone G (2016) Alzheimer neuropathology without frontotemporal lobar degeneration hallmarks (TAR DNA-binding protein 43 inclusions) in missense progranulin mutation Cys139Arg. Brain Pathol, doi: 10.1111/bpa. 12480

[19] Kelley BJ, Haidar W, Boeve BF, Baker M, Shiung M, Knopman DS, Rademakers R, Hutton M, Adamson J, Kuntz KM, Dickson DW, Parisi JE, Smith GE, Petersen RC (2010) Alzheimer disease-like phenotype associated with the c.154delA mutation in progranulin. Arch Neurol 67, 171-177.

[20] Cortini F, Fenoglio C, Guidi I, Venturelli E, Pomati S, Marcone A, Scalabrini D, Villa C, Clerici F, Dalla Valle E, Mariani C, Cappa S, Bresolin N, Scarpini E, Galimberti D (2008) Novel exon 1 progranulin gene variant in Alzheimer's disease. Eur J Neurol 15, 1111-1117.

[21] Rademakers R, Dermaut B, Peeters K, Cruts M, Heutink P, Goate A, Van Broeckhoven C (2003) Tau (MAPT) mutation Arg406Trp presenting clinically with Alzheimer disease does not share a common founder in Western Europe. Hum Mutat 22, 409-411.

[22] Brouwers N, Nuytemans K, van der Zee J, Gijselinck I, Engelborghs S, Theuns J, Kumar-Singh S, Pickut BA, Pals P, Dermaut B, Bogaerts V, De Pooter T, Serneels S, Van den Broeck M, Cuijt I, Mattheijssens M, Peeters K, Sciot R, Martin JJ, Cras P, Santens P, Vandenberghe R, De Deyn PP, Cruts M, Van Broeckhoven C, Sleegers K (2007) Alzheimer and Parkinson diagnoses in progranulin null mutation carriers in an extended founder family. Arch Neurol 64, 1436-1446.

[23] Cacace R, Van Cauwenberghe C, Bettens K, Gijselinck I, van der Zee J, Engelborghs S, Vandenbulcke M, Van Dongen J, Bäumer V, Dillen L, Mattheijssens M, Peeters K, Cruts M, Vandenberghe R, De Deyn PP, Van Broeckhoven C, Sleegers K (2013) C9orf72 G4C2 repeat expansions in Alzheimer's disease and mild cognitive impairment. Neurobiol Aging 34, 1712.e1-7.

[24] Zhu JB, Tan CC, Tan L, Yu JT (2017) State of play in Alzheimer's disease genetics. JAlzheimers Dis 58, 631-659.

[25] Lambert JC, Heath S, Even G, Campion D, Sleegers K, Hiltunen M, Combarros O, Zelenika D, Bullido MJ, Tavernier B, Letenneur L, Bettens K, Berr C, Pasquier F, Fiévet
N, Barberger-Gateau P, Engelborghs S, De Deyn P, Mateo I, Franck A, Helisalmi S, Porcellini E, Hanon O, European Alzheimer's Disease Initiative Investigators, de Pancorbo MM, Lendon C, Dufouil C, Jaillard C, Leveillard T, Alvarez V, Bosco P, Mancuso M, Panza F, Nacmias B, Bossú P, Piccardi P, Annoni G, Seripa D, Galimberti D, Hannequin D, Licastro F, Soininen H, Ritchie K, Blanché H, Dartigues JF, Tzourio C, Gut I, Van Broeckhoven C, Alpérovitch A, Lathrop M, Amouyel P (2009) Genome- wide association study identifies variants at CLU and CR1 associated with Alzheimer's disease. Nat Genet 41, 1094-1099.

[26] Harold D, Abraham R, Hollingworth P, Sims R, Gerrish A, Hamshere ML, Pahwa JS, Moskvina V, Dowzell K, Williams A, Jones N, Thomas C, Stretton A, Morgan AR, Lovestone S, Powell J, Proitsi P, Lupton MK, Brayne C, Rubinsztein DC, Gill M, Lawlor B, Lynch A, Morgan K, Brown KS, Passmore PA, Craig D, McGuinness B, Todd S, Holmes C, Mann D, Smith AD, Love S, Kehoe PG, Hardy J, Mead S, Fox N, Rossor M, Collinge J, Maier W, Jessen F, Schürmann B, Heun R, van den Bussche H, Heuser I, Kornhuber J, Wiltfang J, Dichgans M, Frölich L, Hampel H, Hüll M, Rujescu D, Goate AM, Kauwe JS, Cruchaga C, Nowotny P, Morris JC, Mayo K, Sleegers K, Bettens K, Engelborghs S, De Deyn PP, Van Broeckhoven C, Livingston G, Bass NJ, Gurling H, McQuillin A, Gwilliam R, Deloukas P, AlChalabi A, Shaw CE, Tsolaki M, Singleton AB, Guerreiro R, Mühleisen TW, Nöthen MM, Moebus S, Jöckel KH, Klopp N, Wichmann HE, Carrasquillo MM, Pankratz VS, Younkin SG, Holmans PA, O'Donovan M, Owen MJ, Williams J (2009) Genome-wide association study identifies variants at CLU and PICALM associated with Alzheimer's disease. Nat Genet 41, 1088-1093.

[27] Seshadri S, Fitzpatrick AL, Ikram MA, DeStefano AL, Gudnason V, Boada M, Bis JC, Smith AV, Carassquillo MM, Lambert JC, Harold D, Schrijvers EM, Ramirez-Lorca R, Debette S, Longstreth WT Jr, Janssens AC, Pankratz VS, Dartigues JF, Hollingworth P, Aspelund T, Hernandez I, Beiser A, Kuller LH, Koudstaal PJ, Dickson DW, Tzourio C, Abraham R, Antunez C, Du Y, Rotter JI, Aulchenko YS, Harris TB, Petersen RC, Berr C, Owen MJ, Lopez-Arrieta J, Varadarajan BN, Becker JT, Rivadeneira F, Nalls MA, Graff-Radford NR, Campion D, Auerbach S, Rice K, Hofman A, Jonsson PV, Schmidt H, Lathrop M, Mosley TH, Au R, Psaty BM, Uitterlinden AG, Farrer LA, Lumley T, Ruiz A, Williams J, Amouyel P, Younkin SG, Wolf PA, Launer LJ, Lopez OL, van Duijn CM, Breteler MM; CHARGE Consortium; GERAD1 Consortium; EADI1 Consortium (2010) Genome-wide analysis of genetic loci associated with Alzheimer disease. JAMA 303, 1832-1840.

[28] Naj AC, Jun G, Beecham GW, Wang LS, Vardarajan BN, Buros J, Gallins PJ, Buxbaum JD, Jarvik GP, Crane PK, Larson EB, Bird TD, Boeve BF, Graff-Radford NR, De Jager PL, Evans D, Schneider JA, Carrasquillo MM, ErtekinTaner N, Younkin SG, Cruchaga C, Kauwe JS, Nowotny P, Kramer P, Hardy J, Huentelman MJ, Myers AJ, Barmada MM, Demirci FY, Baldwin CT, Green RC, Rogaeva E, St George-Hyslop P, Arnold SE, Barber R, Beach T, Bigio EH, Bowen JD, Boxer A, Burke JR, Cairns NJ, Carlson CS, Carney RM, Carroll SL, Chui HC, Clark DG, Corneveaux J, Cotman CW, Cummings JL, DeCarli C, DeKosky ST, Diaz-Arrastia R, Dick M, Dickson DW, Ellis WG, Faber KM, Fallon KB, Farlow MR, Ferris S, Frosch MP, Galasko DR, Ganguli M, Gearing M, Geschwind DH, Ghetti B, Gilbert JR, Gilman S, Giordani B, Glass JD, Growdon JH, Hamilton RL, Harrell LE, Head E, Honig LS, Hulette CM, 
Hyman BT, Jicha GA, Jin LW, Johnson N, Karlawish J, Karydas A, Kaye JA, Kim R, Koo EH, Kowall NW, Lah JJ, Levey AI, Lieberman AP, Lopez OL, Mack WJ, Marson DC, Martiniuk F, Mash DC, Masliah E, McCormick WC, McCurry SM, McDavid AN, McKee AC, Mesulam M, Miller BL, Miller CA, Miller JW, Parisi JE, Perl DP, Peskind E, Petersen RC, Poon WW, Quinn JF, Rajbhandary RA, Raskind M, Reisberg B, Ringman JM, Roberson ED, Rosenberg RN, Sano M, Schneider LS, Seeley W, Shelanski ML, Slifer MA, Smith CD, Sonnen JA, Spina S, Stern RA, Tanzi RE, Trojanowski JQ, Troncoso JC, Van Deerlin VM, Vinters HV, Vonsattel JP, Weintraub S, Welsh-Bohmer KA, Williamson J, Woltjer RL, Cantwell LB, Dombroski BA, Beekly D, Lunetta KL, Martin ER, Kamboh MI, Saykin AJ, Reiman EM, Bennett DA, Morris JC, Montine TJ, Goate AM, Blacker D, Tsuang DW, Hakonarson H, Kukull WA, Foroud TM, Haines JL, Mayeux R, Pericak-Vance MA, Farrer LA, Schellenberg GD (2011) Common variants at MS4A4/MS4A6E, CD2AP, CD33 and EPHA1 are associated with late-onset Alzheimer's disease. Nat Genet 43, 436-441.

[29] Hollingworth P, Harold D, Sims R, Gerrish A, Lambert JC, Carrasquillo MM, Abraham R, Hamshere ML, Pahwa JS, Moskvina V, Dowzell K, Jones N, Stretton A, Thomas C, Richards A, Ivanov D, Widdowson C, Chapman J, Lovestone S, Powell J, Proitsi P, Lupton MK, Brayne C, Rubinsztein DC, Gill M, Lawlor B, Lynch A, Brown KS, Passmore PA, Craig D, McGuinness B, Todd S, Holmes C, Mann D, Smith AD, Beaumont H, Warden D, Wilcock G, Love S, Kehoe PG, Hooper NM, Vardy ER, Hardy J, Mead S, Fox NC, Rossor M, Collinge J, Maier W, Jessen F, Rüther E, Schürmann B, Heun R, Kölsch H, van den Bussche H, Heuser I, Kornhuber J, Wiltfang J, Dichgans M, Frölich L, Hampel H, Gallacher J, Hüll M, Rujescu D, Giegling I, Goate AM, Kauwe JS, Cruchaga C, Nowotny P, Morris JC, Mayo K, Sleegers K, Bettens K, Engelborghs S, De Deyn PP, Van Broeckhoven C, Livingston G, Bass NJ, Gurling H, McQuillin A, Gwilliam R, Deloukas P, Al-Chalabi A, Shaw CE, Tsolaki M, Singleton AB, Guerreiro R, Mühleisen TW, Nöthen MM, Moebus S, Jöckel KH, Klopp N, Wichmann HE, Pankratz VS, Sando SB, Aasly JO, Barcikowska M, Wszolek ZK, Dickson DW, Graff-Radford NR, Petersen RC, the Alzheimer's Disease Neuroimaging Initiative, van Duijn CM, Breteler MM, Ikram MA, Destefano AL, Fitzpatrick AL, Lopez O, Launer LJ, Seshadri S, consortium CHARGE, Berr C, Campion D, Epelbaum J, Dartigues JF, Tzourio C, Alpérovitch A, Lathrop M, EADI1 consortium, Feulner TM, Friedrich P, Riehle C, Krawczak M, Schreiber S, Mayhaus M, Nicolhaus S, Wagenpfeil S, Steinberg S, Stefansson H, Stefansson K, Snædal J, Björnsson S, Jonsson PV, Chouraki V, Genier-Boley B, Hiltunen M, Soininen $\mathrm{H}$, Combarros O, Zelenika D, Delepine M, Bullido MJ, Pasquier F, Mateo I, Frank-Garcia A, Porcellini E, Hanon O, Coto E, Alvarez V, Bosco P, Siciliano G, Mancuso M, Panza F, Solfrizzi V, Nacmias B, Sorbi S, Bossú P, Piccardi P, Arosio B, Annoni G, Seripa D, Pilotto A, Scarpini E, Galimberti D, Brice A, Hannequin D, Licastro F, Jones L, Holmans PA, Jonsson T, Riemenschneider M, Morgan K, Younkin SG, Owen MJ, O'Donovan M, Amouyel P, Williams J (2011) Common variants at ABCA7, MS4A6A/MS4A4E, EPHA1, $\mathrm{CD} 33$ and CD2AP are associated with Alzheimer's disease. Nat Genet 43, 429-435.

[30] Jun G, Naj AC, Beecham GW, Wang LS, Buros J, Gallins PJ, Buxbaum JD, Ertekin-Taner N, Fallin MD, Friedland R, Inzelberg R, Kramer P, Rogaeva E, St George-Hyslop
P, Alzheimer's Disease Genetics Consortium, Cantwell LB, Dombroski BA, Saykin AJ, Reiman EM, Bennett DA, Morris JC, Lunetta KL, Martin ER, Montine TJ, Goate AM, Blacker D, Tsuang DW, Beekly D, Cupples LA, Hakonarson H, Kukull W, Foroud TM, Haines J, Mayeux R, Farrer LA, Pericak-Vance MA, Schellenberg GD (2010) Meta-analysis confirms CR1, CLU, and PICALM as alzheimer disease risk loci and reveals interactions with APOE genotypes. Arch Neurol 67, 1473-1484.

[31] Lambert JC, Ibrahim-Verbaas CA, Harold D, Naj AC, Sims R, Bellenguez C, Jun G, Destefano AL, Bis JC, Beecham GW, Grenier-Boley B, Russo G, Thornton-Wells TA, Jones N, Smith AV, Chouraki V, Thomas C, Ikram MA, Zelenika D, Vardarajan BN, Kamatani Y, Lin CF, Gerrish A, Schmidt H, Kunkle B, Dunstan ML, Ruiz A, Bihoreau MT, Choi SH, Reitz C, Pasquier F, Hollingworth P, Ramirez A, Hanon O, Fitzpatrick AL, Buxbaum JD, Campion D, Crane PK, Baldwin C, Becker T, Gudnason V, Cruchaga C, Craig D, Amin N, Berr C, Lopez OL, De Jager PL, Deramecourt V, Johnston JA, Evans D, Lovestone S, Letenneur L, Morón FJ, Rubinsztein DC, Eiriksdottir G, Sleegers K, Goate AM, Fiévet N, Huentelman MJ, Gill M, Brown K, Kamboh MI, Keller L, Barberger-Gateau P, McGuinness B, Larson EB, Green R, Myers AJ, Dufouil C, Todd S, Wallon D, Love S, Rogaeva E, Gallacher J, St George-Hyslop P, Clarimon J, Lleo A, Bayer A, Tsuang DW, Yu L, Tsolaki M, Bossú P, Spalletta G, Proitsi P, Collinge J, Sorbi S, Sanchez-Garcia F, Fox NC, Hardy J, Naranjo MC, Bosco P, Clarke R, Brayne C, Galimberti D, Mancuso M, Matthews F, European Alzheimer's Disease Initiative (EADI), Genetic, Environmental Risk in Alzheimer's Disease (GERAD), Alzheimer's Disease Genetic Consortium (ADGC), Cohorts for Heart, Aging Research in Genomic Epidemiology (CHARGE), Moebus S, Mecocci P, Del Zompo M, Maier W, Hampel H, Pilotto A, Bullido M, Panza F, Caffarra P, Nacmias B, Gilbert JR, Mayhaus M, Lannfelt L, Hakonarson H, Pichler S, Carrasquillo MM, Ingelsson $\mathrm{M}$, Beekly $\mathrm{D}$, Alvarez V, Zou F, Valladares O, Younkin SG, Coto E, Hamilton-Nelson KL, Gu W, Razquin C, Pastor P, Mateo I, Owen MJ, Faber KM, Jonsson PV, Combarros O, O'Donovan MC, Cantwell LB, Soininen H, Blacker D, Mead S, Mosley TH Jr, Bennett DA, Harris TB, Fratiglioni L, Holmes C, de Bruijn RF, Passmore P, Montine TJ, Bettens K, Rotter JI, Brice A, Morgan K, Foroud TM, Kukull WA, Hannequin D, Powell JF, Nalls MA, Ritchie K, Lunetta KL, Kauwe JS, Boerwinkle E, Riemenschneider M, Boada M, Hiltunen M, Martin ER, Schmidt R, Rujescu D, Wang LS, Dartigues JF, Mayeux R, Tzourio C, Hofman A, Nöthen MM, Graff C, Psaty BM, Jones L, Haines JL, Holmans PA, Lathrop M, PericakVance MA, Launer LJ, Farrer LA, van Duijn CM, Van Broeckhoven C, Moskvina V, Seshadri S, Williams J, Schellenberg GD, Amouyel P (Genet) (2013) Meta-analysis of 74,046 individuals identifies 11 new susceptibility loci for Alzheimer's disease. Nat 45, 1452-1458.

[32] Reitz C, Jun G, Naj A, Rajbhandary R, Vardarajan BN, Wang LS, Valladares O, Lin CF, Larson EB, Graff-Radford NR, Evans D, De Jager PL, Crane PK, Buxbaum JD, Murrell JR, Raj T, Ertekin-Taner N, Logue M, Baldwin CT, Green RC, Barnes LL, Cantwell LB, Fallin MD, Go RC, Griffith P, Obisesan TO, Manly JJ, Lunetta KL, Kamboh MI, Lopez OL, Bennett DA, Hendrie H, Hall KS, Goate AM, Byrd GS, Kukull WA, Foroud TM, Haines JL, Farrer LA, PericakVance MA, Schellenberg GD, Mayeux R (2013) Alzheimer Disease Genetics Consortium, Variants in the ATP-binding cassette transporter (ABCA7), apolipoprotein E in4, and the 
risk of late-onset Alzheimer disease in African Americans. JAMA 309, 1483-1492.

[33] Miyashita A, Koike A, Jun G, Wang LS, Takahashi S, Matsubara E, Kawarabayashi T, Shoji M, Tomita N, Arai H, Asada T, Harigaya Y, Ikeda M, Amari M, Hanyu H, Higuchi S, Ikeuchi T, Nishizawa M, Suga M, Kawase Y, Akatsu H, Kosaka K, Yamamoto T, Imagawa M, Hamaguchi T, Yamada M, Morihara T, Takeda M, Takao T, Nakata K, Fujisawa Y, Sasaki K, Watanabe K, Nakashima K, Urakami K, Ooya T, Takahashi M, Yuzuriha T, Serikawa K, Yoshimoto S, Nakagawa R, Kim JW, Ki CS, Won HH, Na DL, Seo SW, Mook-Jung I, Alzheimer Disease Genetics Consortium, St George-Hyslop P, Mayeux R, Haines JL, Pericak-Vance MA, Yoshida M, Nishida N, Tokunaga K, Yamamoto K, Tsuji S, Kanazawa I, Ihara Y, Schellenberg GD, Farrer LA, Kuwano R, Collaborators: Albert MS, Albin RL, Apostolova LG, Arnold SE, Baldwin CT, Barber R, Barmada MM, Barnes LL, Beach TG, Beecham GW, Beekly D, Bennett DA, Bigio EH, Bird TD, Blacker D, Boeve BF, Bowen JD, Boxer A, Burke JR, Buxbaum JD, Cairns NJ, Cantwell LB, Cao C, Carlson CS, Carney RM, Carrasquillo MM, Carroll SL, Chui HC, Clark DG, Corneveaux J, Crane PK, Cribbs DH, Crocco EA, Cruchaga C, De Jager PL, DeCarli C, DeKosky ST, Demirci F, Dick M, Dickson DW, Duara R, Ertekin-Taner N, Evans D, Faber KM, Fallon KB, Farlow MR, Ferris S, Foroud TM, Frosch MP, Galasko DR, Ganguli M, Gearing M, Geschwind DH, Ghetti B, Gilbert JR, Gilman S, Glass JD, Goate AM, Graff-Radford NR, Green RC, Growdon JH, Hakonarson H, Hamilton-Nelson KL, Hamilton RL, Hardy J, Harrell LE, Head E, Honig LS, Huentelman MJ, Hulette CM, Hyman BT, Jarvik GP, Jicha GA, Jin LW, Kamboh M, Karydas A, Kauwe JS, Kaye JA, Kim R, Koo EH, Kowall NW, Kramer JH, Kramer P, Kukull WA, LaFerla FM, Lah JJ, Larson EB, Leverenz JB, Levey AI, Li G, Lin CF, Lieberman AP, Lopez OL, Lunetta KL, Lyketsos CG, Mack WJ, Marson DC, Martin ER, Martiniuk F, Mash DC, Masliah E, McCormick WC, McCurry SM, McDavid AN, McKee AC, Mesulam M, Miller BL, Miller CA, Miller JW, Montine TJ, Morris JC, Murrell JR, Myers AJ, Naj AC, Olichney JM, Pankratz VS, Parisi JE, Peskind E, Petersen RC, Pierce A, Poon WW, Potter H, Quinn JF, Raj A, Rajbhandary RA, Raskind M, Reiman EM, Reisberg B, Reitz C, Ringman JM, Roberson ED, Rogaeva E, Rosen HJ, Rosenberg RN, Sano M, Saykin AJ, Schneider JA, Schneider LS, Seeley WW, Smith AG, Sonnen JA, Spina S, Stern RA, Tanzi RE, Trojanowski JQ, Troncoso JC, Tsuang DW, Valladares O, Van Deerlin VM, Van Eldik LJ, Vardarajan BN, Vinters HV, Vonsattel JP, Weintraub S, Welsh-Bohmer KA, Williamson J, Woltjer RL, Wright CB, Younkin SG, Yu CE, Yu L (2013) SORL1 is genetically associated with late-onset Alzheimer's disease in Japanese, Koreans and Caucasians. PLoS One 8, e58618.

[34] Saunders AM, Strittmatter WJ, Schmechel D, GeorgeHyslop PH, Pericak-Vance MA, Joo SH, Rosi BL, Gusella JF, Crapper-MacLachlan DR, Alberts MJ, Hulette C, Crain B, Goldgaber D, Roses AD (1993) Association of apolipoprotein E allele epsilon 4 with late-onset familial and sporadic Alzheimer's disease. Neurology 43, 1467-1472.

[35] Sorbi S, Nacmias B, Forleo P, Latorraca S, Gobbini I, Bracco L, Piacentini S, Amaducci L (1994) ApoE allele frequencies in Italian sporadic and familial Alzheimer's disease. Neurosci Lett 177, 100-102.

[36] Sorbi S, Nacmias B, Forleo P, Piacentini S, Amaducci L (1996) Alzheimer's disease and apolipoprotein E in Italy. Ann N Y Acad Sci 777, 260-265.
[37] Genin E, Hannequin D, Wallon D, Sleegers K, Hiltunen M, Combarros O, Bullido MJ, Engelborghs S, De Deyn P, Berr C, Pasquier F, Dubois B, Tognoni G, Fiévet N, Brouwers N, Bettens K, Arosio B, Coto E, Del Zompo M, Mateo I, Epelbaum J, Frank-Garcia A, Helisalmi S, Porcellini E, Pilotto A, Forti P, Ferri R, Scarpini E, Siciliano G, Solfrizzi V, Sorbi S, Spalletta G, Valdivieso F, Vepsäläinen S, Alvarez V, Bosco P, Mancuso M, Panza F, Nacmias B, Bossú P, Hanon O, Piccardi P, Annoni G, Seripa D, Galimberti D, Licastro F, Soininen H, Dartigues JF, KambohMI, Van Broeckhoven C, Lambert JC, Amouyel P, Campion D (2011) APOE and Alzheimer disease: A major gene with semi-dominant inheritance. Mol Psychiatry 16, 903-907.

[38] Cozza A, Melissari E, Iacopetti P, Mariotti V, Tedde A, Nacmias B, Conte A, Sorbi S, Pellegrini S (2008) SNPs in neurotrophin system genes and Alzheimer's disease in an Italian population. J Alzheimers Dis 15, 61-70.

[39] Nacmias B, Tedde A, Bagnoli S, Cellini E, Guarnieri BM, Piacentini S, Sorbi S (2009) Implication of GAB2 gene polymorphism in Italian patients with Alzheimer's disease. J Alzheimers Dis 16, 513-515.

[40] Allen SJ, Dawbarn D (2006) Clinical relevance of the neurotrophins and their receptors. Clin Sci (Lond) 110, 175-191.

[41] Yu M, Luo J, Yang W, Wang Y, Mizuki M, Kanakura Y, Besmer P, Neel BG, Gu H (2006) The scaffolding adapter Gab2, via Shp-2, regulates kit-evoked mast cell proliferation by activating the Rac/JNK pathway. J Biol Chem $\mathbf{2 8 1}$, 28615-28626.

[42] Nacmias B, Tedde A, Bagnoli S, Lucenteforte E, Cellini E, Piaceri I, Guarnieri BM, Bessi V, Bracco L, Sorbi S (2010) Lack of implication for CALHM1 P86Lcommon variation in Italian patients with early and late onset Alzheimer's disease. J Alzheimers Dis 20, 37-41.

[43] Lescai F, Pirazzini C, D’Agostino G, Santoro A, Ghidoni R, Benussi L, Galimberti D, Federica E, Marchegiani F, Cardelli M, Olivieri F, Nacmias B, SorbiS, Bagnoli S, Tagliavini F, Albani D, Martinelli Boneschi F, Binetti G, ForloniG, Quadri P, Scarpini E, Franceschi C (2010) Failure to replicate an association ofrs5984894 SNP in the PCDH11X gene in a collection of 1,222 Alzheimer's disease affected patients. J Alzheimers Dis 21, 385-388.

[44] Piaceri I, Bagnoli S, Lucenteforte E, Mancuso M, Tedde A, Siciliano G, Piacentini S, Bracco L, Sorbi S, Nacmias B (2011) Implication of a genetic variant at PICALM in Alzheimer's disease patients and centenarians. JAlzheimers Dis 24, 409-413.

[45] Sorbi S, Nacmias B, Forleo P, Piacentini S, Latorraca S, Amaducci L (1995) Epistatic effect of APP717 mutation and apolipoprotein E genotype in familial Alzheimer's disease. Ann Neurol 38, 124-127.

[46] Piaceri I, Raspanti B, Tedde A, Bagnoli S, Sorbi S, Nacmias B (2015) Epigenetic modifications in Alzheimer's disease: Cause or effect? J Alzheimers Dis 43, 1169-1173.

[47] Iraola-Guzmán S, Estivill X, Rabionet R (2011) DNA methylation in neurodegenerative disorders: A missing link between genome and environment? Clin Genet 80, 1-14.

[48] Portela A, Esteller M (2010) Epigenetic modifications and human disease. Nat Biotechnol 28, 1057-1068.

[49] Milici A, Salbaum JM, Beyereuther K (1990) Study of the Alzheimer's A4 precursor gene promoter region by genomic sequencing using Taq polymerase. Biochem Biophys Res Commun 169, 46-50.

[50] Schwob NG, Nalbantoglu J, Hastings KE, Mikkelsen T, Cashman NR (1990) DNA cytosine methylation in brain of patients with Alzheimer's disease. Ann Neurol 28, 91-94. 
[51] Lauria M, Echegoyen-Nava RA, Rodríguez-Ríos D, Zaina S, Lund G (2017) Inter-individual variation in DNA methylation is largely restricted to tissue-specific differentially methylated regions in maize. BMC Plant Biol 17, 52.

[52] Ladd-Acosta C, Pevsner J, Sabunciyan S, Yolken RH, Webster MJ, Dinkins T, Callinan PA, Fan JB, Potash JB, Feinberg AP (2007) DNA methylation signatures within the human brain. Am J Hum Genet 81, 1304-1315.

[53] Cecchi C, Fiorillo C, Sorbi S, Latorraca S, Nacmias B, Bagnoli S, Nassi P, Liguri G (2002) Oxidative stress and reduced antioxidant defenses in peripheral cells from familial Alzheimer's patients. Free Radic Biol Med 33, 1372-1379.

[54] Cecchi C, Fiorillo C, Baglioni S, Pensalfini A, Bagnoli S, Nacmias B, Sorbi S, Nosi D, Relini A, Liguri G (2007) Increased susceptibility to amyloid toxicity in familial Alzheimer's fibroblasts. Neurobiol Aging 28, 863-876.

[55] Evangelisti E, Zampagni M, Cascella R, Becatti M, Fiorillo C, Caselli A, Bagnoli S, Nacmias B, Cecchi C (2014) Plasma membrane injury depends on bilayer lipid composition in Alzheimer's disease. J Alzheimers Dis 41, 289-300.

[56] Li T, Pires C, Nielsen TT, Waldemar G, Hjermind LE, Nielsen JE, Dinnyes A, Holst B, Hyttel P, Freude KK (2016) Generation of induced pluripotent stem cells (iPSCs) from an Alzheimer's disease patient carrying a M146I mutation in PSEN1. Stem Cell Res 16, 334-337.

[57] Pen AE, Jensen UB (2017) Current status of treating neurodegenerative disease with induced pluripotent stem cells. Acta Neurol Scand 135, 57-72.

[58] Lauretti E, Iuliano L, Praticò D (2017) Extra-virgin olive oil ameliorates cognition and neuropathology of the $3 \times \mathrm{Tg}$ mice: Role of autophagy. Ann Clin Transl Neurol 4, 564-574.

[59] Grossi C, Ed Dami T, Rigacci S, Stefani M, Luccarini I, Casamenti F (2014) Employing Alzheimer disease animal models for translational research: Focus on dietary components. Neurodegener Dis 13, 131-134.

[60] Associazione italiana ricerca alzheimer ONLUS. http://www.airalzh.it. Last updated June 2017. 